Canadian

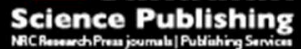

Canadian Journal of Forest Research Revue canadienne de recherche forestière

\title{
Riparian Forest Structure and Stream Geomorphic Condition: Implications for Flood Resilience
}

\begin{tabular}{|r|l|}
\hline Journal: & Canadian Journal of Forest Research \\
\hline Manuscript ID & cjfr-2016-0327.R1 \\
\hline Danuscript Type: & Article \\
\hline Complete List of Authors: & $\begin{array}{l}\text { Keeton, William; University of Vermont } \\
\text { Copeland, Erin; University of Vermont, Rubenstein School of Environment } \\
\text { and Natural Resources } \\
\text { Sullivan, S. Mazeika ; Ohio State University, School of Environment and } \\
\text { Natural Resources } \\
\text { Watzin, Mary; North Carolina State University, College of Natural } \\
\text { Resources }\end{array}$ \\
\hline Keyword: & $\begin{array}{l}\text { Stream ecosystems, riparian forest structure, stream geomorphology, } \\
\text { watershed management, flood resilience }\end{array}$ \\
\hline &
\end{tabular}


2

Revision, November 28, 2016

Canadian Journal of Forest Research

Running Head: Riparian forest structure and stream geomorphic condition

Riparian Forest Structure and Stream Geomorphic Condition: Implications for Flood Resilience William S. Keeton ${ }^{1}$, Erin M. Copeland, Mazeika S.P. Sullivan, and Mary C. Watzin

William S. Keeton

Rubenstein School of Environment and Natural Resources

University of Vermont

Burlington, VT 05405

Telephone: (802) 656-2518

Fax (802) 656-2623

Email: william.keeton@uvm.edu

Erin M. Copeland

Rubenstein School of Environment and Natural Resources

University of Vermont

Burlington, VT 05405

Telephone: (802) 656-2518

Email: ecopeland@pittsburghparks.org

\section{S. Mažeika P. Sullivan}

School of Environment and Natural Resources

The Ohio State University

2021 Coffey Road

Columbus, OH 43210

Telephone: 614-292-7314

Email: sullivan.191@osu.edu

Mary C. Watzin

College of Natural Resources

Room 2028A, Biltmore Hall

North Carolina State University

Raleigh, NC 27695

Telephone: 919-515-2883

Email: mary_watzin@ncsu.edu

${ }^{1}$ Corresponding author 
1 ABSTRACT

2 Managing riparian corridors for flood resilience requires understanding of linkages

3 between vegetation condition and stream geomorphology. Stream assessment approaches

4 increasingly use channel morphology as an indicator of stream condition, with only cursory

5 examination of riparian vegetation. Our research (1) examines relationships between stream

6 geomorphic condition - as assessed by Rapid Geomorphic Assessment (RGA) scores - and

7 riparian forest structure; and (2) investigates scale-dependencies in the linkage between land

8 cover and stream geomorphology. We sampled vegetation structure and composition and

9 assessed geomorphic conditions at 32 stream reaches within the Lake Champlain Basin, USA.

10 RGA scores were modeled as a function of structural attributes using Classification and

11 Regression Trees. Landsat coverages were used to delineate land uses within 5 nested spatial

12 scales. Generalized linear models evaluated relationships between land cover and RGA scores.

13 Standard deviation of basal area partitioned the greatest variability in RGA scores, but dead tree

14 density and basal area (positively) and shrub density (negatively) were also significant

15 predictors. RGA was related to forest and agricultural cover at the 2 finest scales. Riparian

16 forest structure is highly dynamic in relation to stand development and disturbance history;

17 simple forest cover information does not capture these differences or their influences on stream

18 geomorphic condition.

19 


\section{KEY WORDS}

2 Stream ecosystems, riparian forest structure, stream geomorphology, watershed management, 3 flood resilience

\section{INTRODUCTION}

In the wake of two major hurricanes/storms within the last five years (Tropical Storm

7 Irene, 2011; Hurricane Sandy, 2012), managing riparian corridors for flood resilience is a

8 pressing concern in the U.S. Northeast and other regions. Developing a better understanding of

9 linkages between vegetation condition and stream channel geomorphology is vital for informing

10 these efforts. Stream condition assessment approaches (both physical and biological) in the

11 United States and globally have used channel geomorphology as an indicator of ecological

12 condition (Rowntree and Wadeson 2000, MDDNR 2001, Southerland et al. 2003; Sullivan et al.

13 2004, Sullivan and Watzin 2008, Sullivan 2012, Valero et al. 2015). While the structure of

14 riparian forest stands is known to influence in-stream aquatic habitat characteristics and energy

15 flows (Warren et al. 2016), for instance through the provisioning of shade and organic matter,

16 most empirical studies on this topic in the United States have been conducted in the West (Bilby

17 and Ward 1991, Fetherston et al. 1995, Naiman et al. 1998, Naiman et al. 2000b, Warren et al.

18 2013). Recent research has increased our understanding of riparian forest structure and

19 dynamics in northeastern U.S. stream systems (e.g., Hughes and Cass 1997, Keeton et al. 2007,

20 Laser et al. 2009, Morris et al. 2010, Bechtold et al. In press). Riparian forest structure is likely

21 to have important reciprocal relationships with various aspects of stream channel geomorphology

22 and ecological condition, influencing the entrainment and distribution of large wood (LW) and

23 rootwads (Grizzell and Wolf 1998, Gurnell et al. 2002, Warren et al. 2009), bank erosion and 
1 sedimentation (Rabeni and Smale 1995, Gomi et al. 2006, Zaimes and Schultz 2015), channel

2 geometry and adjustment (e.g., channel widening, changes in meanders) (Hession et al. 2003,

3 Sullivan et al. 2004, Sweeney et al. 2004), chemical water quality (Souza et al. 2013, Fernandes

4 et al. 2014), and energy dynamics (Gregory et al. 1991, Naiman et al. 2000). Thus, riparian

5 forest condition may represent an indirect (through linkages with geomorphology), though

6 important, control on both in-stream habitat characteristics and streamflow regimes (Thorne

7 1990, Johnson 1994, Shields 1995, Tabacchi et al. 1998, Rahmeyer et al. 1999). Riparian forest

8 control on stream geomorphology has previously been termed "forced morphology"

9 (Montgomery and Buffington 1997).

10 Understanding relationships between riparian forest structure and stream condition is

11 particularly important in human-dominated landscapes, such as northern New England, where

12 land-use history has dramatically altered forest age-class distributions (Lorimer 2001, Lorimer

13 and White 2003, Nislow 2005) as well as the distribution and structure of forest vegetation

14 (Foster et al. 1998, Cogbill 2000, Fuller et al. 2004). These changes are likely to have altered

15 structure-related riparian forest functions, such as organic matter input and storage (Keeton et al.

16 2007, Warren et al 2009), flood dispersion (Rahmeyer et al. 1999), sediment retention and

17 transport (Fetherston et al. 1995), and the composition and abundance of riverine biotic

18 communities (Jones et al. 1999, Warren et al. 2016). Interest in these relationships has recently

19 spiked in light of the severe flooding and impacts of Hurricane Irene, a post-tropical, high

20 precipitation storm that struck portions of Vermont and other northeastern U.S. states in late

21 August 2011. Regional interest is thus very high in managing for resilience to extreme weather

22 events, including strategies designed to maintain floodplain integrity and conserve forest cover in

23 sub-watersheds important for flood resiliency (Watson et al. 2016). Our study, employing data 
1 collected prior to Hurricane Irene (August 2011), establishes baseline relationships that may help

2 inform studies of the very dramatic perturbations, such as mass wasting events and wood inputs

3 into streams, caused by this and future extreme events. We focus on a mixture of streams and

4 small rivers, including lower-gradient systems and their associated alluvial floodplains, for

5 which relatively few studies have investigated forest-stream interactions in the U.S. Northeast.

\section{$7 \quad 1.1$ Stream geomorphic condition}

8 Our research examines relationships between forest structure and stream geomorphic condition

9 using a protocol called Rapid Geomorphic Assessment (RGA, see below). As outlined in

10 Sullivan et al. (2006), stream geomorphic condition represents the deviation of a channel from

11 morphological characteristics of a reference, equilibrium reach based on dominant channel

12 adjustment processes: degradation (incising), widening, aggradation, and planform change.

13 Streams are in a state of dynamic equilibrium when sediment transport (i.e., stream discharge

14 and sediment particle size) equals stream power (e.g., stream flow and slope) (Lane 1955).

15 Equilibrium (also referred to as stream stability) is lost when one of the variables changes,

16 requiring one or more of the other variables to increase or decrease proportionally to maintain

17 equilibrium (Lane and Richards 1997, Sullivan et al. 2004). Such disequilibria, due to the

18 formidable force of water and sediment, can lead to significant changes in stream channel form

19 and structure (Pizzuto et al. 2000, Hession 2001). Streams in equilibrium typically exhibit

20 minimal alteration in course from year to year, move water and sediment load in balance, and are

21 characterized by minor bank changes and natural erosion. Conversely, adjusting streams can

22 change course by meters per year, cut new channels, have large sections of collapsing banks,

23 widen and/or cut deeper into the channel, and can have heavy silt and sediment deposits in 
1 natural pools. In order to re-equilibrate, channels generally pass through a sequence of stages.

2 These include incising, widening, and eventually re-stabilizing in a new geometry, as

3 conceptualized in channel evolution models presented by Schumm (1977) and Schumm et al.

4 (1984).

5 The RGA is a semi-quantitative evaluation designed to synthesize channel condition using

6 field indicators related to channel adjustment (e.g., bank erosion, sediment deposition, channel

7 avulsion, entrenchment, connectivity to floodplain, etc.; VTDEC 2003 and Sullivan et al. 2006)

8 and stage of channel evolution. RGA scores are useful for assessing stream geomorphic

9 condition at the reach scale (typically $10^{1}-10^{2} \mathrm{~m}$ ) and have been shown to be reflective of more

10 quantitative channel evaluations and to help define past and/or current mechanisms of channel

11 adjustment. Higher RGA scores correlate with more stable channel configurations (VTDEC

12 2003) and have been shown to be tightly linked to aquatic biota (Sullivan et al. 2004, Sullivan et

13 al. 2006, Sullivan and Watzin 2008).

14 The RGA is one of several techniques used to prioritize stream reaches for restoration,

15 protection, and management in the U.S. (MDDNR 2001, VTDEC 2003, Rosgen 1996) and

16 abroad (e.g., Rowntree and Wadeson 2000, King and Day 2002). Other methods focus more

17 directly on aquatic biota (e.g., Karr 1981, Davis and Simon 1995, Barbour et al. 1999) rather

18 than on geomorphology. As a reach-scale assessment, the RGA is typically used in conjunction

19 with watershed-scale analyses. While limited by its semi-quantitative nature, the RGA is

20 actively used by natural resource agencies because it provides a low cost and efficient

21 assessment tool for linking geomorphic condition with anthropogenic land use (Jokay and

22 Watson 2005). Changes on the landscape have the potential to affect channel evolution, and

23 thereby RGA scores, through the modification of water and sediment yields. Moreover, the 
1 RGA is typically used as one of several indicators of stream corridor condition and thus can be

2 combined with other information (e.g. biotic, chemical, etc.) in ecological assessments (Sullivan 3 and Watzin 2008).

4

$5 \quad 1.2$ Effects of riparian forests on stream-channel dynamics

Riparian forests are known to regulate water and sediment movement into stream

7 channels (Endreny 2002, Sweeney et al. 2004). However, research on interactions between

8 vegetation and stream morphology has mostly compared forested streams to unforested streams

9 (Murgatroyd 1983, Sweeney et al. 2004, Anderson et al. 2004, Hession et al. 2003, Allmendinger

10 2005). Similarly, stream condition assessments often identify presence/absence and extent of

11 riparian forest cover but involve few or no quantitative measurements, such as plot-based

12 sampling, of forest structure (Rowntree and Wadeson 2000, MDDNR 2001, VTDEC 2003).

13 We tested the hypothesis that stream geomorphic condition, as measured by reach-scale

14 RGA scores, in northern hardwood-conifer systems is influenced not by the presence or absence

15 of forest cover alone, but varies with differences in stand structure among reaches. This is likely

16 because stand structure influences coarse root density and thus bank stability (Michelli and

17 Kirchner 2002), water dissipation during flooding (Rahmeyer et al 1999), and in-stream

18 geomorphic processes related to LW inputs (Bilby and Likens 1980, Montgomery and

19 Buffington 1997, Gurnell et al 2005, Keeton et al 2007, Kraft et al. 2011).

\section{$21 \quad 1.3$ Scale-dependent land cover - stream geomorphology interactions}

22 Stream geomorphic condition scores are often used to prioritize stream reaches for

23 restoration, yet the scale at which land cover and vegetation condition affect geomorphology is 
1 not consistently determined. Relationships attributed to proximate effects (i.e., a change within

2 the adjacent riparian area) may reflect upstream or watershed-scale effects or the cumulative

3 effects of processes operating at multiple spatial scales. This has the potential to cause a

4 decoupling between the scale at which restoration and conservation activities are conducted and

5 the scales at which deleterious influences occur. With the increasing emphasis and financial

6 expenditure devoted to stream, river, and riparian restoration throughout the United States

7 (Bernhardt et al 2005), and the use of RGA scores to prioritize restoration projects, it is essential

8 to understand scale-dependencies in mechanisms of geomorphic change. Therefore, we tested a

9 second hypothesis that reach-scale RGA scores correlate with forest cover at multiple spatial

10 scales, ranging from $50 \mathrm{~m}$ on either side of river reaches to entire watersheds $\left(3.7-509 \mathrm{~km}^{2}\right.$

11 drainage area). This is likely because upstream land use has the potential to alter sediment and

12 water supply, which are important drivers of channel evolution.

\section{2. METHODS}

\section{$15 \quad 2.1$ Study area}

16 Our study area encompasses the Vermont, U.S.A. portion of the Lake Champlain Basin

17 (Figure 1). It has a depositional history of marine, lake, and large river sediments. These soils

18 provide the region's most agriculturally productive soils. The valley has gentle to rolling

19 topography and is bounded to the east by the Green Mountains, a northern extension of the

20 Appalachian Range. Elevations range from $29 \mathrm{~m}$ to approximately $550 \mathrm{~m}$ above sea level with

21 annual precipitation averaging $76 \mathrm{~cm}$. Lake Champlain drains five major rivers: the Missisquoi,

22 Lamoille, Winooski, LaPlatte, and Poultney. The Champlain Valley in Vermont has been 
1 farmed since the late 1700 's; it is $62 \%$ forested and $28 \%$ agricultural, with the remainder in

2 wetlands, urban/suburban development, and other land-cover classes (Meals and Budd 1998).

$4 \quad 2.2$ Selection of study streams

We sampled 32 third to fifth order stream reaches (Table 1) within the Lake Champlain

6 Valley. Reach drainage areas ranged in size from 3.7 to $509 \mathrm{~km}^{2}$, with an average of

7 approximately $110 \mathrm{~km}^{2}$. We chose reaches in streams flowing through a range of land-cover

8 types and habitat conditions. Reaches were $>10$ bankfull channel widths in length and

9 encompassed a range of bed morphologies, including pool-riffle and plane bed, as described by

10 Montgomery and Buffington (1997). Vegetation surrounding the reaches ranged from non-

11 forested (e.g. agricultural or wet meadow) to fully forested (floodplain or upland forest).

12 Forested vegetation in the Champlain Valley is dominated by northern hardwoods and northern

13 hardwood-conifer forest types (Thompson and Sorenson 2000), although remnant stands of

14 clayplain forest exist (abundant pre-19 $9^{\text {th }}$ century), which include central hardwood species

15 (Cogbill et al. 2002).

\section{$17 \quad 2.3$ Data collection}

$18 \quad 2.3 .1$ Vegetation inventory

19 Stream reaches selected for study were delineated on 0.5-m resolution digital orthophoto

20 quadrangles (Figure 2). Stream channels were buffered to $50 \mathrm{~m}$ on both sides in a geographic

21 information system (ESRI ArcMap 8.0). We then stratified within buffered reaches, digitizing

22 polygons by vegetation patch type. Based on orthophoto interpretation and field validation,

23 vegetation patches were classified as upland forest, floodplain forest, floodplain non-forest (wet 
1 meadow), agricultural, or agricultural buffer (e.g., un-mowed grass). Vegetation classification

2 also incorporated information on landforms. Upland forest (UF) was designated as the forested

3 land extending beyond the first terrace of the river. Floodplain forest (FF) encompassed forests

4 located on a primary floodplain or first terrace and supporting facultative or obligate floodplain

5 tree species. Floodplain non-forest (FNF) was dominated by herbaceous or shrub species; this

6 was always located on a primary floodplain or $1^{\text {st }}$ terrace adjacent to a river. Vegetation

7 sampling plots were randomly distributed as a proportionate sample of each patch type based on

8 its relative abundance within the buffered area along each reach. This yielded a total of 12-25

9 plots per reach depending on the diversity and relative extent of different vegetation types

10 (Shivers and Borders 1996).

11 Forest vegetation composition and structure were sampled within variable radius plots,

12 using a 2.3-(metric) basal area factor prism. In each plot, all trees (live and dead) $>5 \mathrm{~cm}$

13 diameter at breast height $(\mathrm{dbh})$ were identified, measured at breast height $(1.37 \mathrm{~m})$, and assessed

14 for decay class (1 [live] - 7 [highly decayed]). Tree saplings ( $>1 \mathrm{~m}$ in height, $<5 \mathrm{~cm} \mathrm{dbh})$ and

15 woody shrubs were inventoried (density by species) using a point-quarter-distance sample

16 centered within each prism plot. LW volume (downed $\operatorname{logs} \geq 10 \mathrm{~cm}$ diameter at intercept, $\geq 1 \mathrm{~m}$

17 length) was sampled using a line intercept method following Warren et al (2008). LW transects

18 were placed systematically to connect sample plots and were thus of variable length (approx. 30

19 to $100 \mathrm{~m}$ ) and orientation, resulting in well distributed spatial surveys.

\section{$21 \quad 2.3 .2$ Rapid Geomorphic Assessments (RGA)}

22 We used the RGA protocols developed by VTDEC (2003) to assess stream reaches. This

23 protocol is based on evidence of channel adjustment focusing on dominant geomorphic 
1 processes: degradation (incision), aggradation (accumulation of sediment), widening (bank

2 erosion), and planform change (channel meander pattern). For each geomorphic adjustment

3 process, a suite of field indicators is used to assign a rating from 0 to 20 ( 0 represents gross

4 channel instability, 20 represents channel equilibrium). Ratings for the four channel adjustments

5 (degradation, aggradation, widening, change in planform) are summed into a composite value for

6 the stream reach (maximum score $=80$ ). This value is then divided by 80 to yield an overall

7 RGA score, expressed as a proportion. Thresholds within this continuous scale were used to

8 assign stream reaches to discrete condition categories: reference $(0.85-1)$, good $(0.65-0.84)$,

9 fair $(0.35-0.64)$, or poor $(0-0.34)$ generally following Sullivan et al. (2006). Our dataset

10 included only one site rated "poor," which limited our ability to determine relationships for this

11 portion of the RGA scale.

\section{$13 \quad 2.4$ Data analysis}

$14 \quad 2.4 .1$ Analysis of vegetation structure

15 Vegetation inventory data were input into the Northeast Decision Model (NED-2, Twery

16 et al. 2005) and spreadsheet-based programs to generate vegetation structural metrics, including

17 metrics indicative of stand stocking and density, tree sizes and variation among size classes,

18 large tree abundance, and dead wood both standing and downed. Coarse root biomass was

19 estimated using species-group specific allometric equations from Jenkins et al. (1993). The

20 parameters and equations, developed specifically for coarse roots, use the component ratio

21 method to predict the proportion of total tree biomass in roots based on aboveground live-tree

22 measurements (for the equations, see Jenkins et al. 1993, p. 24). Structural variables were

23 calculated independently for each patch type (FNF, FF, and UF). Reach-specific means were 
1 calculated by weighting patch type-specific averages by their proportional representation of

2 within each site. This resulted in values that reflect the relative degree of influence of each

3 vegetation patch type on stream reach condition. A correlation matrix was generated to reduce

4 the number of variables examined in statistical analyses. When two or more variables were

5 highly correlated $(r>0.75)$ with one another, we selected the variable most indicative of

6 overstory structure, sapling/shrub layers, or LW availability (Table 2).

$7 \quad$ Classification and regression tree (CART) analysis were run in S-Plus software

8 (Statistical Sciences, Inc. 2003) to model RGA scores as a function of multiple vegetation

9 structural characteristics (Table 2). CART is a non-parametric test and able to assess non-linear

10 relationships and high-order interactions (Breiman et al. 1984, De'ath and Fabricius 2000).

11 CART partitions variance in a dependent variable through a series of splits based on values of

12 one or more independent variables. Splits are made where threshold values for an independent

13 variable maximally distinguish values of a dependent variable for a subset of reaches; the latter

14 become branches on each side of the split. Cost-complexity pruning was used to eliminate non-

15 significant nodes $($ alpha $=0.05)$.

16 Linear regression analysis was used to examine potential relationships between the

17 predictor variables selected in CART and RGA scores. This provided a confirmation of the

18 CART results, but was also complementary because regression evaluates variation across all

19 reaches, whereas CART assesses variation among partitioned subsets of reaches. Riparian LW

20 volume was used as a predictor variable due to its relationship with intermediary mechanisms

21 potentially linking forest structure with stream geomorphic condition (Vallet et al. 2002, Gurnell

22 et al. 2005). Riparian LW volume can be strongly correlated with wood recruitment into stream

23 channels (Keeton et al. 2007), and thus provides a useful potential indicator for in-stream LW. 
1 Residuals were checked using the Wilk-Shapiro test, confirming assumptions of normality.

2 When non-linear relationships were evident, we evaluated the relative predictive strength of

3 logarithmic, polynomial, and negative exponential curves fit to the data. One outlier in the

4 dataset was identified using Cook's (D) distance measure.

\subsubsection{Analysis of land cover and RGA scores at multiple spatial scales}

A logical criticism of attributing channel geomorphic condition to proximate effects at

8 the reach scale is that fluvial geomorphology may reflect an influence from upstream or from

9 watershed-scale processes. To examine this question we delineated five, nested spatial scales in

10 ESRI ArcMap 8.0. The first two scales encompassed the area buffered on either side of each

11 stream reach to $50 \mathrm{~m}$ and $100 \mathrm{~m}$. These scales approximate two (50 m buffer) and four (100 m

12 buffer) site potential tree heights, a concept used to scale buffer widths based on functions

13 provided by forest-stream interactions (Gregory 1997). The next three scales encompassed the

14 entire stream network in the 1:5000 Vermont Hydrography dataset (VCGI 2004), including the

15 study reach and all areas upstream. These scales represented: (1) buffering to $50 \mathrm{~m}$ both sides of

16 channels, (2) buffering to $100 \mathrm{~m}$ both sides of channels, and (3) the entire watershed upstream of

17 the study reach. The five scales were designated as follows: 50 meter wide reach (50mR), 100

18 meter wide reach $(100 \mathrm{mR}), 50$ meter wide, upstream watershed $(50 \mathrm{mWS}), 100$ meter wide,

19 upstream watershed (100mWS), and entire upstream watershed (WS). For each scale, we used a

20 supervised classification of the 2002 land-cover layer for the state of Vermont, a combination of

21 three 2002 Landsat-7 ETM+ scenes. We calculated area by land-cover type, classified as

22 agriculture, urban, forested, and other for 25 of the reaches (Table 1). This was not performed

23 for seven reaches for which data were unavailable. 
Kolmogorov-Smirnov goodness-of-fit-tests were used to compare the mean distribution

2 of forest, agricultural, and urban cover at the reach scale $(50 \mathrm{mR})$ to the mean land cover at all

3 four larger scales $(100 \mathrm{mR}, 50 \mathrm{mWS}, 100 \mathrm{mWS}$, and WS $)$. This helped determine if relationships

4 between land cover and RGA scores were truly scale-dependent and not just reflective of

5 differences in cover type distribution at different scales.

6 To determine the potential effect of spatial scale on RGA scores we examined models of

7 land use and RGA scores at the five scales described previously. Generalized Linear Models

8 (GLM) with the Gaussian Link Function (normal distribution) were used to model the

9 relationship between RGA scores and multiple predictor variables: proportion of buffer in

10 agricultural, urban, and forested land for each spatial scale. Normality was confirmed for all

11 dependent variables (RGA score at each scale) using the Wilk-Shapiro test. GLMs yield robust

12 predictions when there are potential non-linear responses in a dependent variable and if

13 heterogeneity of variance is exhibited (Venables 2000). These were of concern for these

14 particular variable combinations.

\section{3. RESULTS}

\section{$17 \quad 3.1$ Reach-scale vegetation structure and RGA scores}

18 The results supported the hypothesis that stream geomorphic condition varies

19 significantly with differences in the forest stand structure and other vegetation characteristics of

20 riparian corridors. When vegetation metrics (Table 2) were included in a CART analysis, four

21 structural variables emerged as important in explaining variance in RGA scores among reaches

22 (Figure 3): standard deviation of total (live and dead tree) basal area (representing spatial

23 variation within individual reaches), mean total basal area, dead tree stem density, and shrub 
1 density. Basal area standard deviation was most predictive of RGA scores. Greater than $5.71 \mathrm{~m}^{2}$

$2 \mathrm{ha}^{-1}$ standard deviations of basal area were associated with RGA scores between 64 and 83 .

3 Condition ratings of reaches with less variation in basal area (i.e., lower basal area standard

4 deviation) ranged from 31 to 57. RGA scores were highest (83) at reaches with basal area

5 standard deviations greater than $5.71 \mathrm{~m}^{2} \mathrm{ha}^{-1}$ (or highly variable basal area) and shrub densities

6 below 1,373 stems ha ${ }^{-1}$ (or relatively low to moderate shrub densities). In general, CART results

7 indicated that greater levels of forest stand structural complexity (e.g., dead tree density and

8 basal area) supported higher RGA scores (Figure 3).

9 Linear regression confirmed that all but one of the variables identified in CART were

10 statistically significant predictors of RGA score across all the reaches, rather than only for

11 subsets of reaches. Both total basal area $\left(R^{2}=0.32, p<0.001\right)$ and the standard deviation of

12 basal area $\left(R^{2}=0.26, p=0.004\right)$ were positively related to RGA score (Figure 4), but the former

13 emerged as the stronger predictor, which contrasted with the CART results. When an outlier

14 (NERCTB, a reach with an unusually low RGA score, see Table 2) was removed from the

15 dataset, variation explained by basal area increased to $37 \%$. Dead tree density (log transformed)

16 retained a weak $\left(R^{2}=0.12\right)$ though statistically significant $(p=0.047)$ relationship with RGA

17 condition rating. When examining the total pool of sites, we did not find a significant

18 relationship between shrub density and RGA score using linear regression, signaling that an

19 association with shrub density was restricted to the partitioned subset of sites as modeled in

20 CART.

21 Total basal area was strongly and positively correlated with allometrically estimated

22 coarse root biomass $\left(R^{2}=0.86, p<0.001\right)$, calculated as an average weighted by the proportion

23 of patch types within each site. Root biomass was in turn positively correlated with RGA score 
$1 \quad\left(R^{2}=0.46, p<0.001\right)$. LW volume within $50 \mathrm{~m}$ of river banks showed a somewhat weak $\left(R^{2}=\right.$

$20.20)$ though statistically significant $(p=0.011)$ and positive relationship with RGA score. This

3 pattern held when the outlier reach (NERCTB) was removed from the dataset. A logarithmic

4 curve $(y=0.959 \operatorname{Ln}(x)-2.837)$ explained the most variation in this relationship.

\subsection{Land cover and RGA scores at multiple spatial scales}

In order to assess scale-dependencies in relationships between land cover and stream condition, it was necessary first to determine if land cover distributions were similar across

9 scales. Goodness-of-fit results (Table 3) showed that percent forest cover within study reaches

$10(50 \mathrm{mR})$ was not significantly different from percent forest at the $100 \mathrm{mR}$. Because of this result,

11 we used the 50mR scale for further comparison against the coarser scales. Percent forest cover

12 within study reaches $(50 \mathrm{mR})$ was not significantly different from the watershed scale (WS).

13 However, percent forest within reaches $(50 \mathrm{mR}$ scales) was different from stream-network scales

14 buffered at both 50mWS scale $(p=0.015)$ and 100mWS scale $(p=0.015)$. Thus, the comparison

15 of $50 \mathrm{mR}$ to WS scales was most robust, with comparison to $50 \mathrm{mWS}$ and $100 \mathrm{mWS}$ less robust

16 due to differences in relative proportions of land-cover types.

17 Our results did not support the hypothesis that RGA scores are correlated with forest

18 cover across all spatial scales, including watershed scales. Rather significant correlations were

19 found only for a subset of the scales we assessed. Results from the GLM's showed that, at the

$2050 \mathrm{mR}$ scale, RGA score was positively and linearly correlated with percent forest cover $(t=$

$213.19, p<0.001)$ and negatively related to percent agricultural land $(t=-3.409, p=<0.001$,

22 Figure 5). RGA score was also positively related to the percentage of each reach in forest and

23 negatively related to the percentage in agricultural land at the $100 \mathrm{mR}$ buffer level (Table 4). 
1 There were no significant relationships between land cover and RGA score at any of the larger

2 (upstream watershed) spatial scales (Table 4). Forest and agricultural land cover were inversely

3 correlated at all scales in our dataset. Urban land use surrounding all but one reach represented a

4 comparatively small (mean $=6 \%)$ percentage of the study watersheds; the lack of correlation

5 with RGA scores in our dataset may have reflected this lack of variability.

\section{4. DISCUSSION}

8 The geomorphic condition of stream channels is correlated with both riparian forest structure and

9 land cover based on our results. This finding has important implications both for our

10 understanding of forest-stream interactions as well as management intended to maintain the

11 integrity of stream networks including flood resilience. Streams running through riparian forests

12 of greater structural complexity (e.g., greater amounts of, and more spatial variation in, basal

13 area) are more likely to exhibit channels in better geomorphic condition. However, given that

14 we did not test causality in our study, the relationships that we found may be due to an effect of

15 forest structure on channel geomorphology or vice versa (e.g., effects of geomorphic and flood

16 related disturbances on forest composition and development [Hughes and Cass 1997, Stromberg

17 et al. 2005]). There is also the possibility of feedback loops, both positive and negative, between

18 forest structure and dynamic channel processes (Johnson et al. 2005). However, our results are

19 consistent with the limited previous research in the eastern U.S. documenting linkages between

20 the structure of deciduous and mixed deciduous-coniferous forests and in-stream habitat

21 characteristics (Hedman et al. 1996, Vallet et al. 2002, Keeton et al. 2007, Warren et al. 2009).

22 We also present initial evidence that relationships between forest cover and stream geomorphic 
1 condition may be scale-dependent. In our study, RGA scores appeared to primarily reflect fine-

2 scale $(50 \mathrm{mR}$ and $100 \mathrm{mR})$ relationships between forest cover and stream geomorphology.

$4 \quad 4.1$ Linkages between riparian forest structure and stream geomorphology

The results support our first hypothesis and point to a relationship between riparian forest

6 structure and stream channel condition in the northern hardwood-conifer systems of our study

7 area. In Vermont's Champlain Valley, forest cover, basal area, and coarse root biomass were

8 positively and linearly related to geomorphic condition as indicated by RGA scores. Basal area

9 provides a good indication of aggregate structural complexity because it is correlated with

10 elements of both vertical and horizontal complexity (Keeton 2006). Previous research provides

11 some basis for interpreting these results with the caveat that we did not directly investigate

12 mechanistic relationships. Greater structural complexity in riparian forests also enhances

13 sediment retention, limits pollution movement, and regulates stream flow, for instance, by

14 reducing overland flow and dampening the intensity of peak flows (Endreny 2002, Bilby and

15 Ward 1991, Rahmeyer et al. 1999, Tabacchi et al. 2000). Trees and their associated root systems

16 increase tensile strength, soil cohesion, and drainage, thereby increasing bank stability as long as

17 root systems extend to the low-water mark (Thorne 1990). Stand age and stem density also

18 influence stream bank and in-channel roughness coefficients, which are adjustments in velocity

19 equations for friction (McKenney et al. 1995). Roughness affects mechanisms that influence

20 channel adjustment, such as sediment transport and flood or peak flow velocities (Graf 1978,

21 Acrement and Schneider 1989, Bendix and Hupp 2000).

22 We found that forested streambanks were correlated with channel integrity, as have

23 others (Bilby and Ward 1991, Sweeney et al. 2004, Sullivan et al. 2007). The structural 
1 characteristics we found to be correlated with RGA scores, including basal area, spatial variation

2 in basal area, and dead tree stem density, generally increase with forest stand development into a

3 late-successional condition in northern hardwood-conifer forests (McGee et al. 1999, Ziegler

4 2002, Burrascano et al. 2013), including riparian systems (Keeton et al, 2007, Curzon and

5 Keeton 2010). For instance, basal-area variation is indicative of horizontal structural

6 development, such as shifting gap mosaics, which is a defining characteristic of late-successional

7 temperate forest development (Runkle 2000, Franklin et al 2002, Franklin and Van Pelt 2004).

8 The canopy disturbances that drive horizontal development play an important role in adding

9 wood to stream channels (Kraft et al. 2002). Thus, while we did not directly investigate whether

10 geomorphic condition is related to late-successional forest structure, our results suggest this topic

11 as worthy of further study.

12 Large wood accumulations in stream channels provide important ecological functions,

13 such as debris dam and plunge-pool formation and associated retention of fine sediment (Bilby

14 and Ward 1991, Montgomery et al 1995, Diez et al 2000, Valett et al 2002). These processes, in

15 turn, can positively influence channel geometry and stability (Gurnell 2002, Kraft et al. 2011).

16 Large wood inputs and associated effects on lower-order stream geomorphology are strongly

17 correlated with riparian stand age and structure in northern-hardwood conifer systems (Keeton et

18 al, 2007, Warren et al. 2009). It was, therefore, surprising that we only found a relatively weak,

19 though statistically significant, relationship (explaining only $20 \%$ of the variance in RGA)

20 between LW volume and channel condition rating along the streams we studied.

21 There are several possible explanations for the relatively weak relationships with LW in

22 our dataset. First we did not measure in-stream LW volume directly, but rather used riparian (or

23 forest floor) LW volume as an indicator of LW input potential. Secondly, whereas LW has been 
1 shown to influence geomorphology in low-gradient river systems in some regions (e.g. Naiman

2 et al 2000a, Wiens 2002), similar relationships have not been well established for mid- to low-

3 gradient systems in the northeastern U.S (but see Montgomery and Buffington 1997 for Pacific

4 Northwest streams). Our reaches had generally low volumes of riparian LW (mean $\left.=21 \mathrm{~m}^{3} \mathrm{ha}^{-1}\right)$

5 relative to means reported for riparian forests along low order stream channels running through

6 mature $\left(86 \mathrm{~m}^{3} \mathrm{ha}^{-1}\right)$ and old-growth $\left(164 \mathrm{~m}^{3} \mathrm{ha}^{-1}\right)$ northern hardwood-conifer forests in the

$7 \quad$ Adirondacks of New York (see Keeton et al 2007). Lack of old-growth forest structure along

8 our stream reaches may also have played a role. The young to mature and managed forests that

9 dominate the region are known to have lower volumes of LW compared to older and unmanaged

10 forests (McGee et al 1999, Angers et al 2005, Keeton et al 2007). Large wood volumes and

11 large log frequency are predicted to increase with forest age in the Northeast (Warren et al.

12 2009).

13 The low riparian LW volumes we observed also may have reflected, in part, the influence

14 of non-forest vegetation (mean $=18 \%$ of total cover) at many of our reaches. It is possible that

15 in this region LW levels are simply too low in proportion to channel size, with wood lengths too

16 short relative to bank full width, to have a strong effect on channel dynamics (Gregory et al.

17 2003). Large wood is less likely to aggregate in debris dams in larger streams ( $>10 \mathrm{~m}$ bankfull

18 width) in the Northeast, compared to intermediate sized streams (6-10 m bank full width, Kraft et

19 al. 2011), which may reduce retention period within larger channels. Finally, Vermont's streams

20 and rivers can experience large ice flows in the spring, which frequently dislocate LW from

21 within channels, although re-deposition can occur with high spring flows. Thus, LW may be

22 relatively less influential in the systems we studied due to a combination of large stream size and

23 disturbance dynamics. 
Interestingly, our CART results also showed that stream geomorphic condition was

2 highest at reaches above a certain level of structural complexity (i.e., basal area standard

3 deviation) in forested patches but below a shrub density threshold in non-forest patches. The

4 latter result clearly corresponded with the exceptionally high shrub densities at reaches

5 dominated by open-canopied, primarily non-forest vegetation, which may, in turn, be related to

6 disturbances (e.g., flooding, geomorphic disturbance, cattle grazing, forest clearing, etc.).

7 Higher shrub densities were thus correlated with lower channel stability. A portion of woody

8 shrub stems were exotic, invasive species ( $7 \%$ on average, but ranging from 0 to $45 \%)$,

9 particularly Japanese knotweed (Fallopia japonica) and shrub honeysuckles (Lonicera sp.).

10 While we did not find a statistically significant relationship between geomorphic condition and

11 invasive shrub density across the full range of sites, several of our sites (identified in CART)

12 with highest invasive densities also had the lowest RGA scores. Spread of invasive shrubs

13 within riparian areas and along floodplains may influence geomorphic condition through

14 reductions in bank stability, an inference also supported by previous research (Hood and Naiman

15 2000). At the same time, flooding and stream geomorphic disturbances are known to facilitate

16 dispersal and establishment of invasive plant species, creating a possible positive feedback

17 between these processes (Stromberg et al. 2007). Therefore, our findings suggest that further

18 research could help elucidate possible connections between invasive plants and stream

19 geomorphic condition in the Lake Champlain Basin.

Our results showed a positive relationship between forested cover within $100 \mathrm{~m}$ of stream

21 channels and geomorphic condition. Forest-stream interactions at this scale are an important

22 consideration for managers interested in riparian buffer design (Gregory et al. 1997). However,

23 our results suggest that forest cover alone does not tell the full story. Rather, it is critical to 
1 examine riparian forest structure, since this might be expected to directly influence fluvial

2 geomorphic condition and is highly dynamic and related to stand age, disturbance history, and

3 human manipulation (Hale et al, 1999; McGee et al, 1999; Angers et al, 2005; Keeton, 2006).

4 We suggest that direct measures of forest structure are an important consideration for stream

5 condition classification and mapping, particularly for key concerns such as bank stability and

6 roughness.

\subsection{Scale-dependent influences of forest structure on channel geomorphology}

9 Expanding the spatial scale of analysis may increase the strength of relationships between

10 vegetation condition and channel condition using RGA and other geomorphic assessments

11 (Wien, 2002). For example, it may be necessary to inspect upstream reaches for sedimentation

12 and flow alterations related to loss or degradation of forest cover (VTDEC, 2003). However,

13 while reach-level relationships between forest structure, land cover, and RGA were statistically

14 significant, a similar relationship at larger spatial scales was not evident in our dataset.

15 Nevertheless, forest cover and reach-scale RGA scores appeared closely related at the 50mR and

$16100 \mathrm{mR}$ scales based on our GLM findings (Table 4). The results of the goodness-of-fit tests

17 suggested that the strength of this relationship at the reach rather than watershed scale was not

18 due a difference in percent forest cover; cover was not significantly different between these

19 scales (Table 3).

20 Channel geomorphology is likely to be affected by land use, and the cover type/condition

21 of vegetation are likely to influence stream geomorphology and hydrology at multiple spatial

22 scales (Ebisemiju,1989; Knox and Hudson, 1995; Ruhlman and Nutter, 1999). Stream

23 characteristics have been correlated with land cover at both stream reach and coarser scales 
1 (Richards et al, 1996; Townsend et al, 1997; Sponseller et al, 2001). For instance, land-cover

2 and vegetation changes at stream reach scales influence bank stability (Zaimes, 2004), while

3 watershed scale land-use impacts (e.g. percent imperviousness surface) influence timing and

4 intensity of peak flows (Jones and Grant, 1996), with corresponding effects on planform

5 adjustment (Allmendinger et al, 2005). However, we infer from both our CART and our GLM

6 results that important forest structure-stream geomorphology interactions occur at within reach

7 scales and that RGA scores strongly reflect localized (reach scale) land cover, primarily

8 agricultural versus forested land cover.

\section{$10 \quad 4.3$ Management implications}

11 We recommend that stream assessment approaches could be enhanced by incorporating

12 forest structural indicators at reach scales, rather than relying on vegetation cover alone. This

13 would be useful where a better understanding of riparian corridor condition is desired. Where

14 feasible, these data could be collected either through field sampling, perhaps conducted in

15 conjunction with RGA protocols, or using high resolution remote sensing techniques, such as

16 light detection and ranging (LIDAR; Goodwin et al 2006). Data for the latter are now available

17 for most of the Vermont portion of the Lake Champlain Basin.

18 Incorporation of forest structure indicators into stream assessment would help managers

19 identify and prioritize areas in need of riparian forest restoration or silvicultural treatment, for

20 instance where these projects would be most likely to help improve channel condition. A

21 pressing management issue is the need to design, restore, and safeguard riverine systems,

22 including location of buildings and infrastructure, in ways that maximizes resilience to flooding

23 (Watson et al. 2016). Forest structure is another indicator that agencies and communities can use 
1 to assess potential flood resilience and prioritize floodplain and riparian forests most in need of

2 protection. This assumes relationships among riparian forest structure, bank roughness, channel

3 geomorphic condition, and the ability of a riverine system to dissipate flood energy and recover

4 more rapidly following high discharge events (Hession et al. 2003, Thomas and Nisbet 2007,

5 Jones et al. 2009).

6

7 6. ACKNOWLEDGEMENTS

8 The authors are grateful for funding provided by the National Center for Environmental

9 Research (NCER) STAR Program, U.S. Environmental Protection Agency, grant number

10 R83059501-0. Additional funding was provided by grants from the Northeastern States

11 Research Cooperative and USDA McIntire-Stennis Forest Research Program. Special thanks to 12 Jarlath O’Neil-Dunne, UVM Spatial Analysis Laboratory, for producing Figure 1.

\section{REFERENCES}

15 Angers, V.A., Messier, C. , Beaudet, M., Leduc, A., 2005. Comparing composition and structure in old16 growth and harvested (selection and diameter-limit cuts) northern hardwood stands in Quebec. Forest

17 Ecology and Management. 217: 275-293. doi:10.1016/j.foreco.2005.06.008.

18 Arcement, G.J., Schneider V., 1989. Guide for selecting Manning's roughness coefficients for natural

19 channels and floodplains. US Geological Survey Water Supply Paper 2339.

20 Allmendinger, N.E., Pizzuto, J.E., Potter, N.P., Johnson, T.E., Hession, W.C., 2005. The influence of 21 riparian vegetation on stream width, Eastern Pennsylvania, USA. GSA Bulletin. 117: 1-15.

22 Anderson, R.J., Bledsoe, B.P., Hession, W.C., 2004. Width of streams and rivers in response to

23 vegetation, bank material, and other factors. Journal of the American Water Resources Association.

24 40: 1159-1172. doi:10.1111/j.1752-1688.2004.tb01576.x. 
1 Barbour, M.T., J. Gerritsen, B.D. Snyder, and J.B. Stribling. 1999. Rapid bioassessment protocols for use in streams and wadeable rivers: periphyton, benthic macroinvertebrates and fish. Second edition. USEPA. EPA 841-B-99-002. Washington, DC. USA.

Bechtold, H.A., E.J., Rosi-Marshall, D.R. Warren, W.S. Keeton, and J.J. Cole. In Press. Forest age influences in-stream ecosystem processes in Northeastern US. Ecosystems.

Bendix, J., Hupp, C.R., 2000. Hydrological and geomorphological impacts on riparian plant communities. Hydrological Processes. 14: 2977-2990. doi:10.1002/1099-1085(200011/12)14:16/17<2977::AIDHYP130>3.0.CO;2-4.

Bernhardt, E.S., Palmer, M.A., Allan, J.D., Alexander, G., Barnas, K., Brooks, S., Carr, J., Clayton, S., Dahm, C., Follstad-Shah, J., Galat, D., Gloss, S., Goodwin, P., Hart, D., Hassett, B., Jenkinson, R., Katz, S., Kondolf, G.M., Lake, P.S., Lave, R., Meyer, J.L., O’Donnell, T.K., Pagano, L., Powell, B., Sudduth, E., 2005. Synthesizing U.S. river restoration efforts. Science. 308: 636-637. doi: 10.1126/science.1109769.

Bilby, R. E., and G. E. Likens. 1980. Importance of organic debris dams in the structure and function of stream ecosystems. Ecology. 61: 1107-1113. doi:10.2307/1936830.

Bilby, R.E., Ward, J.W., 1991. Characteristics and function of large woody debris in streams draining old growth, clear cut, and second growth forests in southwestern Washington. Canadian Journal of Fisheries and Aquatic Sciences. 48: 2499-2508. doi:10.1139/f91-291

Breinman, L. J.H. Friedman, R.A. Olshen, and C.J. Stone. 1984. Classification and Regression Trees. Wadsworth and Brooks-Cole Advanced Books and Software, Pacific Grove, CA. 358 pp.

Burrascano, S., W.S. Keeton, F.M. Sabatini, and C. Blasi. 2013. Commonality and variability in the structural attributes of moist temperate old-growth forests: A global review. Forest Ecology and Management. 291:458-479. doi:10.1016/j.foreco.2012.11.020

Cogbill, C.V. 2000. Vegetation of the presettlement forests of northern New England and New York. Rhodora. 102: 250-276. 
1 Cogbill, C.V., J. Burk, and G. Motzkin. 2002. The forests of presettlement New England, USA: spatial

2 and compositional patterns based on town proprietor surveys. Journal of Biogeography. 29: 1279-

3 1304. doi:10.1046/j.1365-2699.2002.00757.x.

4 Cohen, T. Brierley, G.J, and K. Fryirs. 1996. A geomorphic approach to catchment characterisation. In:

5 G.J. Brierely, K. Fryirs, and T. Cohen (eds.). Geomorphology and river ecology in southeastern

6 Australia: an approach to catchment characterisation. Graduate School of the Environment, Sydney,

$7 \quad$ Australia.

8 Curzon, M.T. and W.S. Keeton. 2010. Spatial characteristics of canopy disturbances in riparian old-

9 growth hemlock-northern hardwood forests, Adirondack Mountains, New York, USA. Canadian

10 Journal of Forest Research. 40: 13-25. doi:10.1139/X09-157.

11 Davis, W.S. and T. P. Simon (editors). Biological Assessment and Criteria - Tools for Water Resource

12 Planning and Decision Making. Lewis Publishers, Boca Raton, FL.

13 De'ath, G., and K. E. Fabricius. 2000. Classification and regression trees: a powerful yet simple technique

14 for ecological data analysis. Ecology 81: 3178-3192. doi:10.1890/0012-

15 9658(2000)081[3178:CARTAP]2.0.CO;2.

16 Diez, J. R., S. Larranaga, A. Elosegi, and J. Pozo. 2000. Effect of removal of wood on streambed stability

17 and retention of organic matter. Journal of the North American Benthological Society. 19: 621-632.

18 Ebisemiju, F.S., 1989. Patterns of stream channel response to urbanization in the humid tropics and their

19 implications of urban land use planning: A case study from southwestern Nigeria. Applied

20 Geomorphology. 9: 273-286.

21 Endreny, T.A. 2002. Forest buffer strips: mapping the water quality benefits. Journal of Forestry. 100:

$22 \quad 35-40$.

23 Fernandes, J. D. F., A.L.T. de Souza, and M.O. Tanaka. 2014. Can the structure of a riparian forest

24 remnant influence stream water quality? A tropical case study. Hydrobiologia 724: 175-185. 
1 Fetherston, K.L., Naiman, R.J., Bilby, R.E., 1995. Large woody debris, physical process, and riparian

144.

Foster, D.R., G. Moskin, and B. Slater. 1998. Land-use history as long-term broad scale disturbance:

regional forest dynamics in central New England. Ecosystems. 1: 96-119. doi:

doi:10.1007/s100219900008

Franklin, J.F. and R. Van Pelt. 2004. Spatial aspects of structural complexity in old-growth forests.

Journal of Forestry. 102: 22-28.

Franklin, J.F., Spies, T.A., Van Pelt, R., Carey, A., Thornburgh, D., Berg, D.R., Lindenmayer, D., Harmon, M., Keeton, W.S., Shaw, D.C., Bible, K., Chen, J., 2002. Disturbances and the structural development of natural forest ecosystems with some implications for silviculture. Forest Ecology and Management. 155: 399-423.

Fuller, J., Foster, D., Motzkin, G., McLachlan, J., Barry, S., 2004. Broadscale forest response to land use and climate change. In Forests in time. Edited by D. Foster and J. Aber. New Haven, U.S.. pp. 101124.

Goodwin, N. R. ,N. C. Coops, and D.S. Culvenor. 2006. Assessment of forest structure with airborne LiDAR and the effects of platform altitude. Remote Sensing of Environment. 103: 140-152.

Graf, W.L., 1978. Fluvial adjustment to the spread of tamarisk in the Colorado Plateau region. GSA Bulletin. 89: 1491-1501.

Gregory, S.V. 1997. Riparian management in the 21 st century. In Creating a forestry for the $21^{\text {st }}$ century: the science of ecosystem management. Edited by K.A. Kohm and J.F. Franklin. Island Press, Washington, DC. pp. 69-86.

Gregory, S.V., Swanson, F.J., McKee, W.A., Cummins, K.W., 1991. An ecosystem perspective of riparian zones. BioScience. 41: 540-551.

Gregory, S. V., K. L. Boyer, and A. M. Gurnell. 2003. The Ecology and Management of Wood in World Rivers. American Fisheries Society, Bethesda, MD, USA. 444 pp. 
1 Gurnell, A., 1997. The hydrological and geomorphological significance of forested floodplains. Global

2 Ecology and Biogeography Letters. 6: 219-229.

3 Gurnell, A., K. Tockner, P. Edwards, and G. Petts. 2005. Effects of deposited wood on biocomplexity of 4 river corridors. Frontiers in Ecology and the Environment. 7: 377-382.

5 Hale, C.M., J. Pastor, and K.A. Rusterholtz. 1999. Comparison of structural and compositional

6 characteristics in old-growth and mature, managed hardwood forests of Minnesota, U.S.A. Canadian

$7 \quad$ Journal of Forest Research. 29: 1479-1489.

8 Hedman, C.W., D.H. Van Lear, W.T. Swank. 1996. In-stream large woody debris loading and riparian

9 forest seral stage associations in the southern Appalachian Mountains. Canadian Journal of Forest

$10 \quad$ Research. 26: 1218-1227.

11 Hession, W. C. 2001. Riparian Forest and Urban Hydrology Influences on Stream Channel Morphology:

12 Implications for Restoration. Proceedings of the American Society of Civil Engineering, Houston, 13 TX, USA.

14 Hession, W.C., Pizzuto, J.E., Johnson, T.E., Horwitz, R.J., 2003. Influence of bank vegetation on channel 15 morphology in rural and urban watersheds. Geology. 31: 147-150.

16 Hickin, E.J., 1984. Vegetation and river channel dynamics. Canadian Geography. 28: 111-126.

17 Hood WG, and R.J. Naiman RJ. 2000. Vulnerability of riparian zones to invasion by exotic vascular 18 plants. Plant Ecology 148: 105-114.

19 Hughes, J.W., Cass, W.B., 1997. Pattern and process of a floodplain forest, Vermont, USA: predicted 20 responses of vegetation to perturbation. Journal of Applied Ecology. 34: $594-612$.

21 Jacobson, R.B., 1995. Spatial controls on patterns of land use induced stream disturbance at the drainage 22 basin scale - an example from gravel-bed streams of the Ozark Plateaus, Missouri. In Natural and 23 anthropogenic influences in fluvial geomorphology. Edited by J.E. Costa et al. eds. American

24 Geophysical Union Geophysical Monograph. 89: 219-239.

25 Jacobson, R.B., Coleman, D., 1986. Stratigraphy and recent evolution of Maryland piedmont floodplains. 26 American Journal of Science. 286: 617-637. 
1 Jacobson, R.B., Pugh, A.L., 1992. Effects of land use and climate shifts on channel instability, Ozark

2 Plateau, Missouri, U.S.A. In Proceedings of the workshop on the effects of global climate change on

3 hydrology and water resources at the catchment scale: Tsukuba, Japan, Japan-U.S. Committee on

4 Hydrology, Water Resources and Global Climate Change, pp. 423-444.

5 Jenkins, J. C., Chomnacky, D.C., Heath, L.S., Birdsey, R.A., 2003. National scale biomass estimators for

$6 \quad$ United States tree species. Forest Science. 49: 12-35.

7 Johnson, B. L., W. B. Richardson, and T. J. Naimo. 1995. Past, present, and future concepts in large river

$8 \quad$ ecology. Bioscience. 45: 134-138.

9 Jokay, N. and B. Watson. Conducting rapid fluvial geomorphic assessments based on the channel

10 evolution model: a case study in Griffin, Georgia. Proceedings of the 2005 Georgia Water Resources

11 Conference. April 25-27, 2005, Athens, Georgia.

12 Jones, J. A. and G. E. Grant. 1996. Peak flow responses to clear-cutting and roads in small and large

13 basins, western Cascades, Oregon. Water Resources Research. 32: 959-974.

14 Jones III, E.B.D., Helfman, G.S., Harper, J.O., and P.V. Bolstad. 1999. Effects of riparian forest removal

15 on fish assemblages in Southern Appalachian streams. Conservation Biology. 13: 1454-1465. doi:

$16 \quad 10.1046 /$ j.1523-1739.1999.98172.x.

17 Jones, J.A., G.L. Achterman, L.A. Augustine, I.F. Creed, P.F. Ffolliott, L. MacDonald, B.C. Wemple.

18 2009. Hydrologic effects of a changing forested landscape - challenges for the hydrological sciences.

19 Hydrological Processes. 23: 2699-2704. doi:10.1002/hyp.7404.

20 Karr, J. R. 1981. Assessment of biotic integrity using fish communities. Fisheries. 6: 21-27.

21 Keeton, W.S. 2006. Managing for late-successional/old-growth characteristics in northern hardwood-

22 conifer forests. Forest Ecology and Management. 235: 129-142.

23 Keeton, W.S., C.E. Kraft, and D.R. Warren. 2007. Mature and old-growth riparian forests: structure,

24 dynamics, and effects on Adirondack stream habitats. Ecological Applications. 17: 852-868. 
1 Knox, J.C., Hudson, J.C., 1995. Physical and cultural change in the driftless area of southwest Wisconsin.

2 In Geographical Excursions in the Chicago Region. Edited by M.P. Conzen., Association of

3 American Geographers, $91^{\text {st }}$ Annual Meeting. Chicago, Illinois. pp. 107-131.

4 Kraft, C. E., R. L. Schneider, and D. R. Warren. 2002. Ice storm impacts on woody debris and debris dam

5 formation in northeastern U.S. streams. Canadian Journal of Fisheries and Aquatic Sciences. 59:

$6 \quad 1677-1684$.

7 Kraft, C., D. Warren, W.S. Keeton. 2011. Identifying the spatial pattern of wood distribution in

8 northeastern North American streams. Geomorphology. 135: 1-7.

9 Lane, E.W. 1955. The importance of fluvial morphology in hydraulic engineering. Proceedings of the

10 American Society of Civil Engineering. 81: 1-17.

11 Lane, S. N. and K. S. Richards. 1997. Linking river channel form and process: time, space and causality

12 revisited. Earth Surface Processes and Landforms. 22: 249-260.

13 Laser M, Jordan J, Nislow . 2009. Riparian forest and instream large wood characteristics, West Branch

14 Sheepscot River, Maine, USA. Forest Ecology and Management. 257: 1558-1565.

15 Lorimer, C.G. 2001. Historical and ecological roles of disturbance in eastern North American forests:

169,000 years of change. Wildlife Society Bulletin. 29: 425-439.

17 Lorimer, C.G. and A.S. White. 2003. Scale and frequency of natural disturbances in the northeastern

18 U.S.: implications for early-successional forest habitats and regional age distributions. Forest

19 Ecology and Management. 185: 41-64.

20 McGee, G.G., D.J. Leopold, and R.D. Nyland. 1999. Structural characteristics of old-growth, maturing,

21 and partially cut northern hardwood forests. Ecological Applications. 9: 1316-1329.

22 McKenny, R., Jacobson, R.B., Wertheimer, R.C., 1995. Woody vegetation and channel morphogenesis in 23 low-gradient, gravel-bed streams in the Ozark Plateaus, Missouri and Arkansas. Geomorphology. 13:

24 175-198. doi:10.1016/0169-555X(95)00034-3. 
1 MDDNR, 2001. Stream Corridor Assessment Survey. Maryland Department of Natural Resources,

2 Watershed Restoration Division, Chesapeake and Coastal Watershed Services. Annapolis Maryland, 3 USA.

4 Micheli, E.R., Kirchner, J.W., 2002. Effect of wet meadow riparian vegetation on stream bank erosion. 2.

5 Measurements of vegetated bank strength and consequences for failure mechanics. Earth Surface

$6 \quad$ Processes and Landform. 27: 687-697.

7 Montgomery, D.R., Buffington, J.M., 1997. Channel-reach morphology in mountain drainage basins.

$8 \quad$ GSA Bulletin. 109: 596-611.

9 Montgomery, D. R., J. M. Buffington, R. D. Smith, K. M. Schmidt, and G. Pess. 1995. Pool spacing in

10 forest channels. Water Resources Research. 31: 1097-1105.

11 Morris AEL, Goebel PC, Palik BJ. 2010. Spatial distribution of large wood jams in streams related to

12 stream-valley geomorphology and forest age in northern Michigan. River Research and Applications.

13 26: 835-847. doi:10.1002/rra.1297.

14 Murgatroyd, A.L., Ternan, J.L., 1983. The impact of afforestation on stream bank erosion and channel

15 form. Earth Surface Processes and Landforms. 8: 357-369.

16 Naiman, R.J., Fetherston, K.L., McKay, S.J., Chen, J., 1998. Riparian Forests. In River ecology and

17 management: lessons from the Pacific coastal ecoregion. Edited by R.J. Naiman and R.E. Springer,

18 New York, New York. pp. 289-323.

19 Naiman, R. J., R. E. Bilby, and P. A. Bisson. 2000a. Riparian ecology and management in the Pacific $20 \quad$ coastal rain forest. BioScience. 50: 996-1011.

21 Naiman, R.J., S.R. Elliott, J.M. Helfield, and T.C. O’Keefe. 2000b. Biophysical interactions and the 22 structure and dynamics of riverine ecosystems: the importance of biotic feedbacks. Hydrobiologia.

23 410: $79-86$.

24 Nakamura, F., Yamada, H., 2005. Effects of pasture development on the ecological functions of riparian 25 forests in Hokkaido in northern Japan. Ecological Engineering. 24: 539-550. 
1 Nislow, KH. 2005. Forest change and stream fish habitat: lessons from 'Olde' and New England. Journal of Fish Biology. 67: 186-204 Supp. B

3 Park, C.C., 1977. Man induced changes in stream channel capacity. In River channel changes. Edited by

$4 \quad$ K.J. Gregory. John Wiley \& Sons Ltd., New York, New York. pp. 121-141.

5 Pizzuto, J. E., W. C. Hession, and M. McBride. 2000. Comparing gravel-bed rivers in paired urban and 6 rural catchments of southeastern Pennsylvania. Geology 28: 79-82. doi:10.1130/0091-

$7 \quad$ 7613(2003)31<832b:CGRIPU>2.0.CO;2.

8 Poff, N.L., Allan, J.D., Bain, M.B., Karr, J.R., Prestegaard, K.L., Richter, B.R., Sparks, R.E., Stromberg, 9 J.C., 1997. The natural flow regime. Bioscience. 47: 769-784.

10 Rahmeyer, W., Werth, D. Jr., Freeman, G.E., 1999. Flow resistance to vegetation in compound Channels 11 and Floodplains. US Army Waterways Report, Contract No. DACW39-94-K-0009.

12 Richards, C., Johnson, L.B., Host, G.E., 1996. Landscape scale influences on stream habitats and biota.

13 Canadian Journal of Fisheries and Aquatic Sciences. 53: 295-311.

14 Rowntree, K., Wadeson, R., 2000. Field manual for channel classification and condition assessment.

15 Institute for Water Quality Studies, Department of Water Affairs and Forestry, NAEBP Report Series $16 \quad$ No 13 Pretoria, South Africa.

17 Ruhlman, M.B., Nutter, W.L., 1999. Channel morphology and overbank flow in the Georgia Piedmont.

18 The Journal of the American Water Resources Association. 35: 277-290.

19 Runkle, J.R. 2000. Canopy tree turnover in old-growth mesic forests of eastern North America. Ecology.

$20 \quad$ 81: $554-567$.

21 Schumm, S.A., 1977. The Fluvial System. John Wiley and Sons, New York, New York. USA.

22 Schumm S.A., M.D. Harvey, and C.C. Watson. 1984. Incised channels: morphology, dynamics and

23 control. Water Resources Publications, Litttleton, Colorado, USA.

24 Shields, F.D., 1995. Prediction of effects of woody debris removal on flow resistance. Journal of 25 Hydrological Engineering. 121: 341-354. 
1 Shivers and Borders, 1996. Sampling techniques for forest resource inventory. Wiley, New York, New $2 \quad$ York, USA.

3 Singer, M.T. and C.G. Lorimer. 1997. Crown release as a potential old-growth restoration approach in 4 northern hardwoods. Canadian Journal of Forest Research. 27: 1222-1232. doi:10.1139/x97-071.

5 Southerland, B.W., 2003. Stream geomorphology and classification in glacial-fluvial valleys of the North 6 Cascade Mountain Range. PhD Dissertation. Washington State University, Pullman, Washington.

7 Souza, A. L. T., D.G. Fonseca, R.A. Libório, and M.O. Tanaka. 2013. Influence of riparian vegetation

8 and forest structure on the water quality of rural low-order streams in SE Brazil. Forest Ecology and

9 Management. 298: 12-18. doi:10.1016/j.foreco.2013.02.022.

10 Sponseller, R.A., Benfield, E.F., Valett, H.M., 2001. Relationships between land use, spatial scale and 11 stream macroinvertebrate communities. Freshwater Biology. 46: 1409-1424. doi:10.1046/j.1365$12 \quad 2427.2001 .00758 . x$

13 Statistical Sciences, Inc. 2003. S-plus statistical software. Statistical Science, Inc., Seattle, Washington. 14 Strahler, A. N.. 1952. Hypsometric (area-altitude) analysis of erosional topology. Geological Society of $15 \quad$ America Bulletin 63: 1117-1142.

16 Stromberg, J.C.; K.J. Bagstad, J.M. Leenhouts, S.J. Lite, and E. Makings. 2005. Effects of stream flow 17 intermittency on riparian vegetation of a semiarid region river (San Pedro River, Arizona). River $18 \quad$ Research and Applications. 21: 925-938. doi:10.1002/rra.858.

19 Stromberg, J.C., S. J. Lite, R. Marler, C. Paradzick. P. B. Shafroth, D. Shorrock. J.M. White, and M.S.

22 Sullivan, S.M.P. 2012. Geomorphic-ecological relationships highly variable between headwater and 23 network mountain streams of northern Idaho, United States. Journal of the American Water Resources Association. 48: 1-12. doi: 10.1111/j.1752-1688.2012.00682.x. 
1 Sullivan, S.M.P., M.C. Watzin, and W.C. Hession. 2004. Understanding stream geomorphic state in relation to ecological integrity: evidence using habitat assessments and macroinvertebrates. Environmental Management. 5: 669-683. doi:10.1007/s00267-004-4032-8.

Sullivan, S.M.P., M.C. Watzin, and W.C. Hession. 2006. Influence of geomorphic condition on stream fish communities in Vermont, USA. Freshwater Biology. 51: 1811-1826. doi:10.1111/j.13652427.2006.01616.x.

Sullivan, S.M.P. and M.C. Watzin. 2008. Relating stream physical habitat condition and concordance of biotic productivity across multiple taxa. Canadian Journal of Fisheries and Aquatic Sciences. 12: 2667-2677. doi:10.1139/F08-165.

Sullivan, S.M.P., M.C. Watzin, and W.S. Keeton. 2007. A riverscape perspective on habitat associations among riverine bird assemblages: implications for conservation. Landscape Ecology. 22: 1169-1186. doi:10.1007/s10980-007-9097-3.

Sweeney, B.W., Bott, T.L., Jackson, J.K., Kaplan, L.A., Newbold, J.D., Standley, L.J., Hession, W.C., Horwitz, R.J., 2004. Riparian deforestation, stream narrowing, and loss of stream ecosystem services. Proceedings of the National Academy of Sciences. 101: 14132-14137.

Tabacchi, E., Lambs, L., Guilloy, H., Planty-Tabacchi, A.M., Muller, E., Decamps, H., 2000. Impacts of riparian vegetation on hydrological process. Hydrological Processes. 14: 2959-2976.

Thomas, H. and T.R. Nisbet. 2007. An assessment of the impact of floodplain woodland on flood flows. Water and Environment Journal. 21: 114-126.

Thompson, E.H., Sorenson, E.R., 2000. Wetland, woodland, wildland. A guide to the natural communities of Vermont. University Press of New England. Hanover, New Hampshire..

Thorne, C.R., 1990. Effects of Vegetation on riverbank erosion and stability. In Vegetation and Erosion. Edited by J.B. Thornes. Wiley, Chester. pp. 123-144.

Townsend, C.R., Downes, B.J., Peacock, K., Arbuckle, C.J., 2004. Scale and the detection of land-use effects on morphology, vegetation and macroinvertebrate communities of grassland streams. Freshwater Biology. 49: 448-462. 
1 Townsend, C.R., Arbuckle, C.J., Crowl, T.A., Scarsbrook, M.R., 1997. The relationship between land use 2 and physiochemistry, food resources and macroinvertebrate communities in tributaries of the Taieri

3 River, New Zealand: a hierarchically scaled approach. Freshwater Biology. 37: 177-191.

4 doi:10.1046/j.1365-2427.1997.00151.x.

5 Trimble, S.W., 1997, Stream channel erosion and change resulting from riparian forests. Geology. 25 :

$6 \quad 467-469$.

7 Twery, M.J., P.D. Knopp, S.A. Thomasma, H. M. Rauscher, D.E. Nute, W.D. Potter, F. Maier, J. Wang,

8 M. Dass, H. Uchiyama, A. Glende, and R.E. Hoffman. 2005. NED-2: A decision support system for

9 integrated forest ecosystem management. Computers and Electronics in Agriculture. 49: 24-43.

10 Valero, E., X. Álvarez, and J. Picos. 2015. An assessment of river habitat quality as an indicator of

11 conservation status. A case study in the Northwest of Spain. Ecological Indicators. 57: 131-138. doi:

$12 \quad$ 10.1016/j.ecolind.2015.04.032.

13 Vallett, H.M., Crenshaw, C.L., Wagner, P.F., 2002. Stream nutrient uptake, forest succession, and

14 biogeochemical theory. Ecology. 83: 2888-2901. doi:10.2307/3072024.

15 Venables, W.N. 2000. Exegeses on linear models. Unpublished paper presented to the S-Plus user's

16 conference, October 8-9, 1998, Washington, DC. Available online at

17 http://www.stats.ox.ac.uk/pub/MASS3/Exegeses.pdf.

18 VCGI. 2004. The Vermont Hydrography Dataset (WaterHydro_VHD). Vermont Center for Geographic

19 Information, Waterbury Vermont, USA.

20 VTDEC. 2003. Stream geomorphic assessment handbook: rapid stream assessment - phase 2 field

21 protocols. Vermont Agency of Natural Resources, Department of Environmental Conservation, Water

22 Quality Division, Waterbury, Vermont, USA.

23 Wallace, J. B., J. R. Webster, and J. L. Meyer. 1995. Influence of log additions on physical and biotic 24 characteristics of a mountain stream. Canadian Journal of Fisheries and Aquatic Sciences. 52: 2120252137. 
1 Warren, D.R., C.E. Kraft, W.S. Keeton, J.S. Nunery, and G.E. Likens. 2009. Dynamics of wood

2 recruitment in streams of the northeastern U.S. Forest Ecology and Management. 258: 804-813.

3 Warren, D.R., W.S. Keeton, H. A. Bechtold, and E.J. Rosi-Marshall. 2013. Comparing streambed light

4 availability and canopy cover in streams with old-growth versus early-mature riparian forests in western

5 Oregon. Aquatic Sciences. 75: 547-558. doi:10.1007/s00027-013-0299-2.

6 Warren, D.R., W.S. Keeton, P. M. Kiffney, M.J. Kaylor, H.A. Bechtold, and John Magee. 2016.

7 Changing forests - changing streams: riparian forest stand development and ecosystem function in 8 temperate headwaters. Ecosphere 7: 1-19.

9 Warren, D.R., W.S. Keeton, C.E. Kraft. 2008. Application of the line-intercept method for estimating

10 wood volume in forested headwater streams. Hydrobiologia 598, 123-130. doi:10.1007/s10750-007-

$119144-8$.

12 Watson, K.B., T. Ricketts, G. Galford, S. Polasky, and J. O'Niel-Dunne. 2016. Quantifying flood

13 mitigation services: the economic value of Otter Creek wetlands and floodplains to Middlebury,

14 Vermont. Ecological Economics 130: 16-24. doi: 10.1016/j.ecolecon.2016.05.015.

15 Wiens, J. A., 2002. Riverine landscapes: taking landscape ecology into the water. Freshwater Biology. 47:

$16 \quad 777-798$.

17 Wolman, M.G., 1967. A Cycle of sedimentation and erosion in urban river channels: Geografiska

18 Annalar. 49A: 385-395.

19 Zaimes, G.N., Schultz, R.C. 2015. Riparian land-use impacts on bank erosion of an incised stream in

20 north-central Iowa, USA. Catena. 125: 61-73. doi: 10.1029/GM089.

21 Zaimes, G.N., Schultz, R.C., Isenhart, T.M., 2004. Stream bank erosion adjacent to riparian forest buffers,

22 row crop fields, and continuously-grazed pastures along Bear Creek in Central Iowa. Journal of Soil

23 and Water Conservation. 59: 19-27.

24 Ziegler, S.S., 2000. A comparison of structural characteristics between old-growth and postfire second-

25 growth hemlock-hardwood forests in Adirondack Park, New York, U.S.A. Global Ecology and

26 Biogeography. 9: 373-389. 
1 Zimmerman, R.C., Goodlett, J.C, Comer, G.H., 1967. The influence of vegetation on channel form of 2 small streams. In: Symposium on river morphology; reports and discussions. International

3 Association of Scientific Hydrology, Commission of Surface Waters. pp. 255-275. 
$1 \quad$ Table 1. Descriptive information for study reaches.

\begin{tabular}{|c|c|c|c|c|c|c|c|c|c|}
\hline $\begin{array}{l}\text { Reach } \\
\text { Number }\end{array}$ & $\begin{array}{l}\text { Reach } \\
\text { I.D. }\end{array}$ & $\begin{array}{l}\text { RGA } \\
\text { Score }\end{array}$ & $\begin{array}{l}\text { Stream } \\
\text { Geomorphic } \\
\text { Condition } \\
\text { Category* }\end{array}$ & $\begin{array}{c}\text { Drainage } \\
\text { area } \\
\left(\mathbf{k m}^{2}\right)\end{array}$ & $\begin{array}{c}\text { Bankfull } \\
\text { (m) }\end{array}$ & $\begin{array}{c}50 \mathrm{mR} \\
\text { Forest } \\
(\%)\end{array}$ & $\begin{array}{c}50 \mathrm{mR} \\
\text { Agriculture } \\
(\%)\end{array}$ & $\begin{array}{c}100 \mathrm{mR} \\
\text { Forest } \\
(\%)\end{array}$ & $\begin{array}{c}100 \mathrm{mR} \\
\text { Agriculture } \\
(\%)\end{array}$ \\
\hline 1 & EPAFR & 0.79 & G & 36.8 & 8.4 & 40 & 53 & 20 & 66 \\
\hline 2 & EPATB & 0.65 & G & 43.9 & 15.8 & 57 & 0 & 17 & 12 \\
\hline 3 & EPABG & 0.73 & G & 32.0 & 12.3 & 88 & 11 & 61 & 18 \\
\hline 4 & EPABB & 0.74 & G & 30.5 & 14.5 & 92 & 0 & 56 & 12 \\
\hline 5 & EPARB & 0.68 & G & 16.6 & 6.7 & 74 & 0 & 60 & 11 \\
\hline 6 & EPABR & 0.56 & $\mathrm{~F}$ & 52.8 & 19.8 & 55 & 34 & 12 & 70 \\
\hline 7 & EPALR & 0.60 & $\mathrm{~F}$ & 34.8 & 10.8 & 55 & 41 & 20 & 29 \\
\hline 8 & EPAMC & 0.61 & $\mathrm{~F}$ & 43.7 & 10.8 & 60 & 27 & 49 & 30 \\
\hline 9 & EPAHR & 0.96 & $\mathrm{R}$ & 160.8 & 22.0 & 88 & 0 & 48 & 13 \\
\hline 10 & ЕРAAB & 0.40 & $\mathrm{~F}$ & 27.9 & 6.6 & 0 & 100 & 0 & 72 \\
\hline 11 & EPAMB & 0.60 & $\mathrm{~F}$ & 33.4 & 12.2 & 72 & 0 & 43 & 36 \\
\hline 12 & EPALP & 0.59 & $\mathrm{~F}$ & 80.9 & 13.8 & 37 & 0 & 17 & 55 \\
\hline 13 & EPALC & 0.84 & G & 195.6 & 24.5 & 81 & 0 & 57 & 8 \\
\hline 14 & EPALO & 0.66 & G & 148.2 & 17.1 & 85 & 0 & 17 & 58 \\
\hline 15 & EPANH & 0.64 & $\mathrm{~F}$ & 219.5 & 20.9 & 77 & 7 & 4 & 57 \\
\hline 16 & EPAMS & 0.66 & G & 173.6 & 25.8 & 98 & 0 & 29 & 23 \\
\hline 17 & EPASB & 0.55 & F & 3.7 & 10.1 & 58 & 0 & 48 & 10 \\
\hline 18 & EPALM & 0.70 & G & 509.2 & 35.2 & 11 & 89 & 13 & 36 \\
\hline 19 & EPANB & 0.48 & $\mathrm{~F}$ & 150.4 & 26.3 & 46 & 39 & 3 & 40 \\
\hline 20 & EPAGR & 0.74 & G & 139.4 & 23.7 & 93 & 0 & 47 & 14 \\
\hline 21 & EPAWB & 0.44 & $\mathrm{~F}$ & 58.7 & 14.6 & 14 & 55 & 13 & 49 \\
\hline 22 & EPAMD & 0.50 & $\mathrm{~F}$ & 240.0 & 33.2 & 13 & 85 & 8 & 41 \\
\hline 23 & EPAST & 0.75 & G & 22.7 & 7.8 & 40 & 52 & 13 & 53 \\
\hline 24 & ЕРАРВ & 0.73 & G & 15.8 & 8.3 & 100 & 0 & 58 & 22 \\
\hline 25 & EPAMR & 0.66 & G & 121.4 & 23.9 & 56 & 22 & 15 & 40 \\
\hline 26 & NERCTB & 0.31 & $\mathrm{P}$ & 55.0 & 29.0 & 40 & 60 & NA & NA \\
\hline 27 & NERCLP2 & 0.64 & $\mathrm{~F}$ & 111.0 & 18.0 & 0 & 0 & NA & NA \\
\hline 28 & NERCLP3 & 0.77 & G & 110.0 & 15.0 & 60 & 30 & NA & NA \\
\hline 29 & NERCLP5 & 0.91 & $\mathrm{R}$ & 80.0 & 16.0 & 30 & 10 & NA & NA \\
\hline 30 & NERCLC2 & 0.66 & G & 200.0 & 21.0 & 30 & 0 & NA & NA \\
\hline 31 & LPMAZ & 0.85 & $\mathrm{R}$ & $N A$ & 18.6 & 100 & 0 & NA & NA \\
\hline 32 & LCMAZ & 0.76 & G & $N A$ & 14.7 & 100 & 0 & NA & NA \\
\hline
\end{tabular}

$2 *$ RGA scores are presented as a proportion with higher scores indicating better stream geomorphic condition:

3 Reference $(0.85-1)$, G: good $(0.65-0.84)$, F: fair $(0.35-0.64)$, P: poor $(0-0.34)$. NA = data not available.

4 50mR: Reach buffered at 50m on both sides of the stream. 100mR: Reach buffered at $100 \mathrm{~m}$ on both sides of the

5 stream. Reaches with unavailable data for the $100 \mathrm{~m}$ buffer were not included in the GLM analysis for that scale. 
1 Table 2. Vegetation metrics used in the Classification and Regression Tree analysis. LW $=$ large

2 wood.

\begin{tabular}{|c|c|c|c|}
\hline \multicolumn{2}{|c|}{ Overstory Structure } & \multirow{2}{*}{$\frac{\text { Sapling/Shrub Layer }}{\text { Sapling density }\left(\text { stems }^{-1}{ }^{-1}\right)}$} & \multirow{2}{*}{$\begin{array}{l}\text { LW Availability } \\
\begin{array}{l}\text { Downed LW volume } \\
\left(\mathrm{m}^{3} \mathrm{ha}^{-1}\right)\end{array}\end{array}$} \\
\hline $\begin{array}{l}\text { Total basal area }\left(\mathrm{m}^{2} \mathrm{ha}^{-1}\right) \text {, } \\
\text { live and dead trees }\end{array}$ & $\begin{array}{l}\text { Dead tree stem density } \\
\left(\text { stems } \mathrm{ha}^{-1}\right)\end{array}$ & & \\
\hline $\begin{array}{l}\text { Standard deviation of total } \\
\text { basal area }\left(\mathrm{m}^{2} \mathrm{ha}^{-1}\right)\end{array}$ & $\begin{array}{l}\text { Large }(>50 \mathrm{~cm} \text { dbh }) \\
\text { live tree stem density } \\
\left(\text { stems } \mathrm{ha}^{-1}\right)\end{array}$ & Shrub density (stems ha $\left.^{-1}\right)$ & \\
\hline $\begin{array}{l}\text { Dead tree basal area }\left(\mathrm{m}^{2}\right. \\
\left.\mathrm{ha}^{-1}\right)\end{array}$ & $\begin{array}{l}\text { Large }(>50 \mathrm{~cm} \text { dbh }) \\
\text { dead tree stem density } \\
\left(\text { stems }^{-1}\right)\end{array}$ & $\begin{array}{l}\text { Proportion of shrubs } \\
\text { sampled that are invasive } \\
\text { species }(\%)\end{array}$ & \\
\hline Stem density $\left(\right.$ stems ha $\left.{ }^{-1}\right)$ & $\begin{array}{l}\text { Quadratic mean } \\
\text { diameter }(\mathrm{cm})\end{array}$ & & \\
\hline
\end{tabular}


1 Table 3. Results of goodness-of-fit tests comparing percent forest cover within $50 \mathrm{~m}$ of stream

2 reaches to larger spatial scales measured upstream of reach bottoms.

Percent forest cover along reaches compared to:

KS value Significance

Percent forest within $50 \mathrm{~m}$

buffering along stream

$0.44 \quad 0.015$

networks

0.015

Percent forest within $100 \mathrm{~m}$

buffering along stream

0.44

0.015

networks

Percent forest within entire upstream watersheds

0.28

0.285

3

4 
2 Table 4. Generalized linear modeling results. RGA score is the dependent variable.

\begin{tabular}{|c|c|c|c|c|c|c|c|c|c|c|}
\hline \multirow{2}{*}{$\begin{array}{c}\text { Cover } \\
(\%)\end{array}$} & \multicolumn{2}{|c|}{$50 m R^{I}$} & \multicolumn{2}{|c|}{$100 m R^{2}$} & \multicolumn{2}{|c|}{$50 m W S^{3}$} & \multicolumn{2}{|c|}{$100 m W S^{4}$} & \multicolumn{2}{|c|}{$W S^{5}$} \\
\hline & Tvalue & Sign & T value & Sign. & T value & Sign. & $t$ value & Sign. & $t$ value & Sign. \\
\hline Forest & 3.19 & 0.001 & 3.15 & 0.002 & -0.541 & 0.589 & -0.248 & 0.804 & -0.231 & 0.817 \\
\hline $\mathrm{Ag}$ & -3.41 & 0.001 & -2.41 & 0.016 & 0.414 & 0.679 & 0.243 & 0.808 & 0.174 & 0.862 \\
\hline Urban & NA & NA & -0.46 & 0.645 & -0.419 & 0.675 & -0.665 & 0.506 & -0.014 & 0.989 \\
\hline
\end{tabular}

3 T0mR: Reach Buffered at $50 \mathrm{~m}$ on both sides of the stream

$4 \quad{ }^{2} 100 \mathrm{mR}$ : Reach Buffered at $100 \mathrm{~m}$ on both sides of the stream

5 50mWS: Entire upstream stream network buffered at $50 \mathrm{~m}$ on both sides of the stream

$6{ }^{4} 100 \mathrm{mWS}$ : Entire upstream stream network buffered at $100 \mathrm{~m}$ on both sides of the stream

$7 \quad{ }^{5}$ WS: Entire upstream watershed.

8 Not applicable (NA) are instances of zero \% coverage.

9

10

11

12

13

14 


3

(1)

\section{Figure Captions}

Figure 1. Location of the 32 study reaches within the Lake Champlain Basin (LCB), Vermont, USA. Topography is indicated by shading and stream order by line thickness (see legend) based on Strahler (1952). Map produced by Dr. Jarlath O’Neil-Dunne, Spatial Analysis Laboratory, University of Vermont.

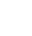

Figure 2. Example of patch type delineation at one of the study sites (EPALP, La Platte River, VT), with photographs of vegetation sampling in floodplain non-forest (top right) and upland forest (bottom right). The area sampled extended $50 \mathrm{~m}$ to either side and a minimum of $10 \mathrm{x}$ channel bankfull width along each stream reach. Each patch was sampled intensively, with the number of plots per patch proportionate to size, yielding a total of 12-25 plots per site.

Figure 3. Classification and regression tree, showing independent variables selected, split values, and partitioned mean values (bottom) of the dependent variable (Rapid Geomorphic Assessment [RGA] scores). Basal areas refer to the total of live and dead trees. Length of each vertical line is proportionate to the amount of deviance explained. Independent variables were selected from an initial set of 11. Minimum observations required for each split $=5$; minimum deviance $=$ $0.01, n=32$. See Table 2 for units of measurement of the independent variables.

1 Figure 4. Results of linear regression analyses predicting RGA as a function of basal area (live and dead, top panel) or the standard deviation of basal area (bottom panel). One outlier (NERCTB) was removed in each of these analyses. With the outlier included, variation explained decreased to $32 \%$ for basal area and $24 \%$ for its standard deviation. $n=32$. 
2 Figure 5. Significant Generalized Linear Models for RGA scores vs. 50mR percent forest cover 3 (top left); RGA vs. 50mR percent agriculture cover (top right); RGA vs. 100mR percent forest

4 cover (bottom left); and RGA vs. 100mR percent agriculture cover (bottom right). Tukey test 5 statistic and $p$-values are generated by the models. $n=25$. 
$1 \quad$ Figure 1.

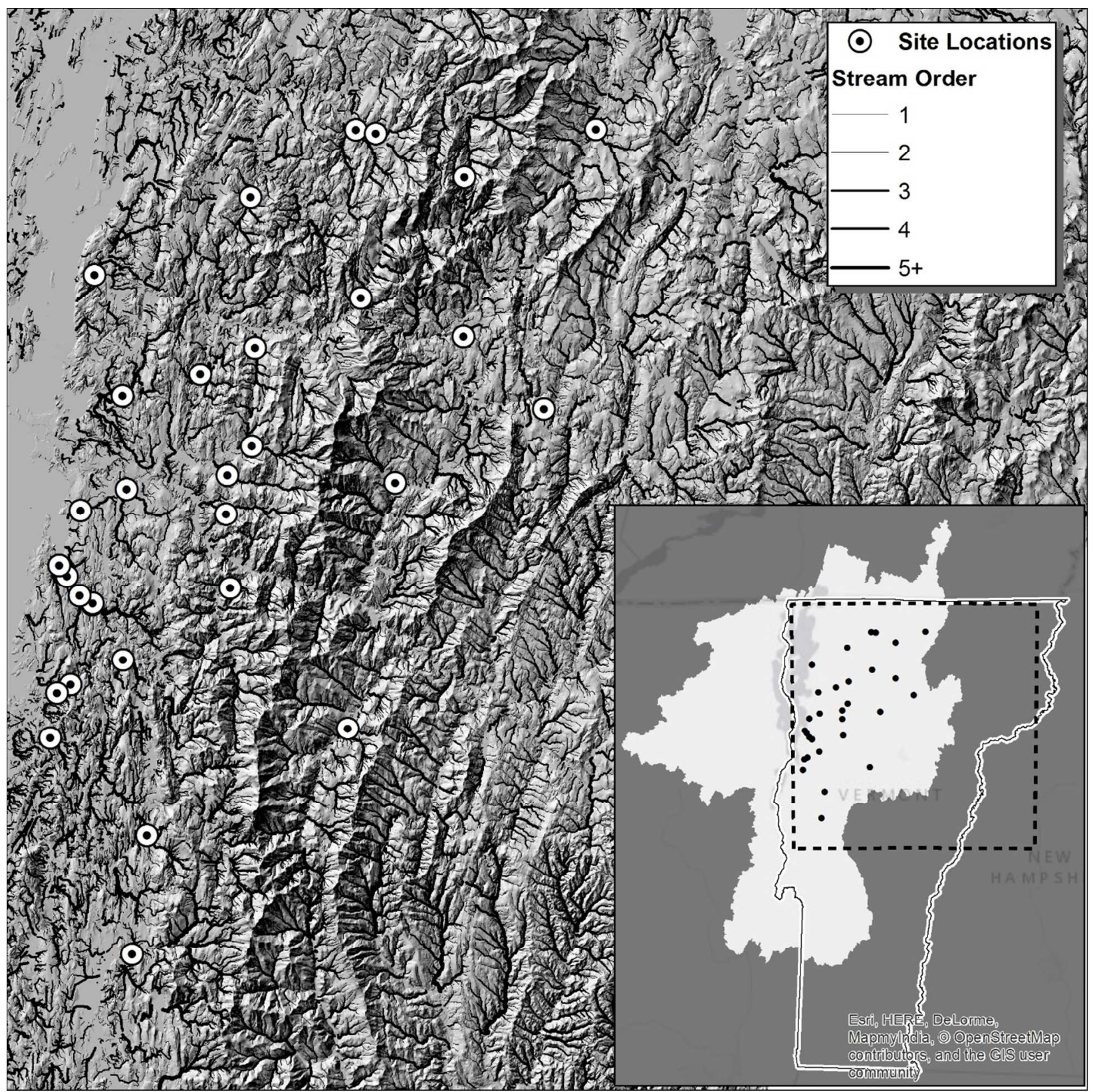


$1 \quad$ Figure 2.

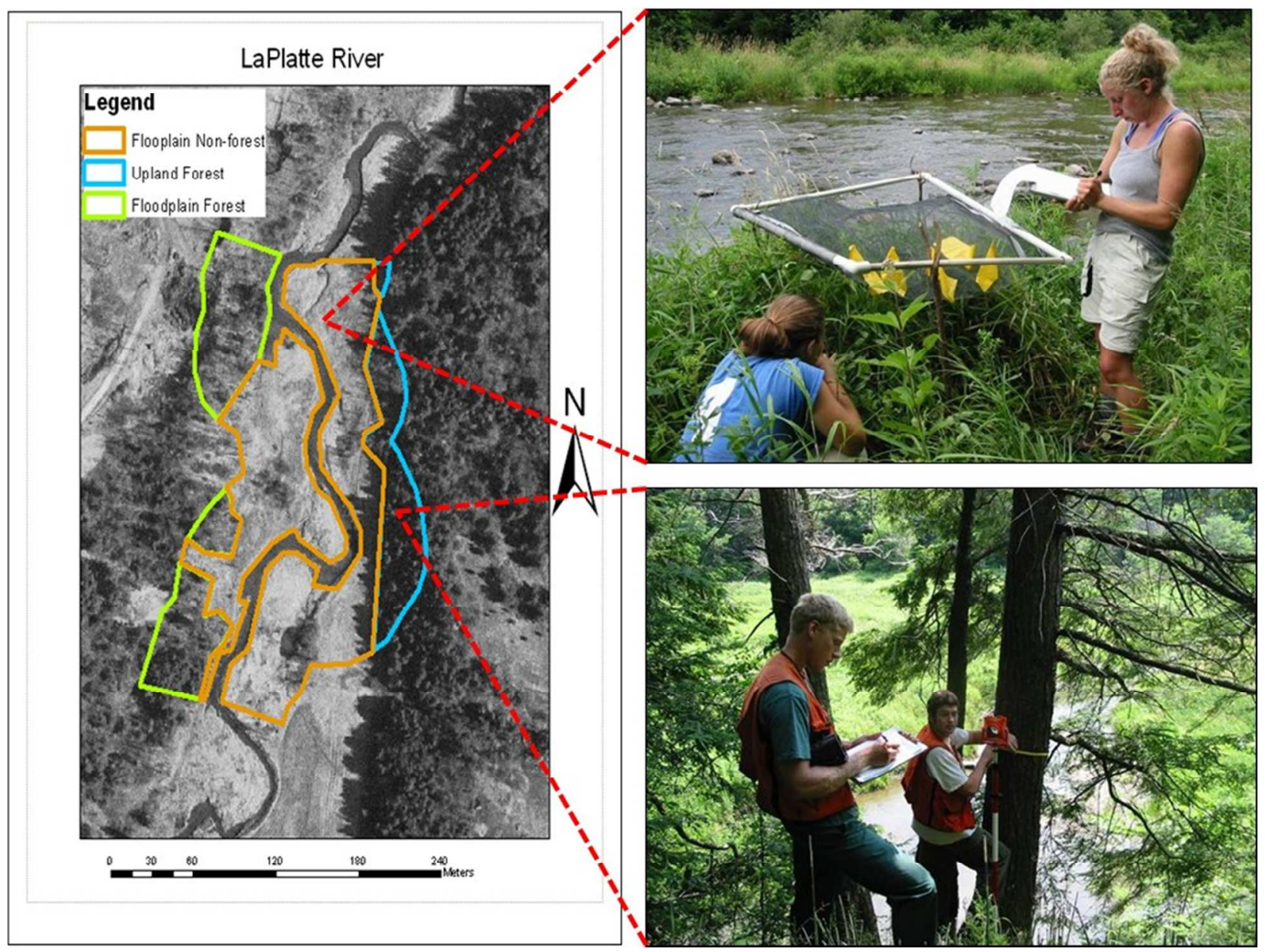


1 Figure 3.

Std. Dev. of Basal Area

$<6 \mathrm{~m}^{2} / \mathrm{ha}$

Std. Dev. of Dead Tree Density

$<33$ stems/ha

2

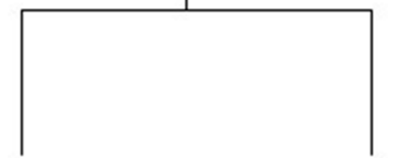

RGA
Score

64

RGA
Score $\left\{\begin{array}{l}52 \\ \end{array}\right.$

$\begin{array}{ll}\text { RGA } & 52 \\ \text { Score } & \end{array}$

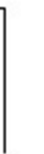

3

4 
$1 \quad$ Figure 4.
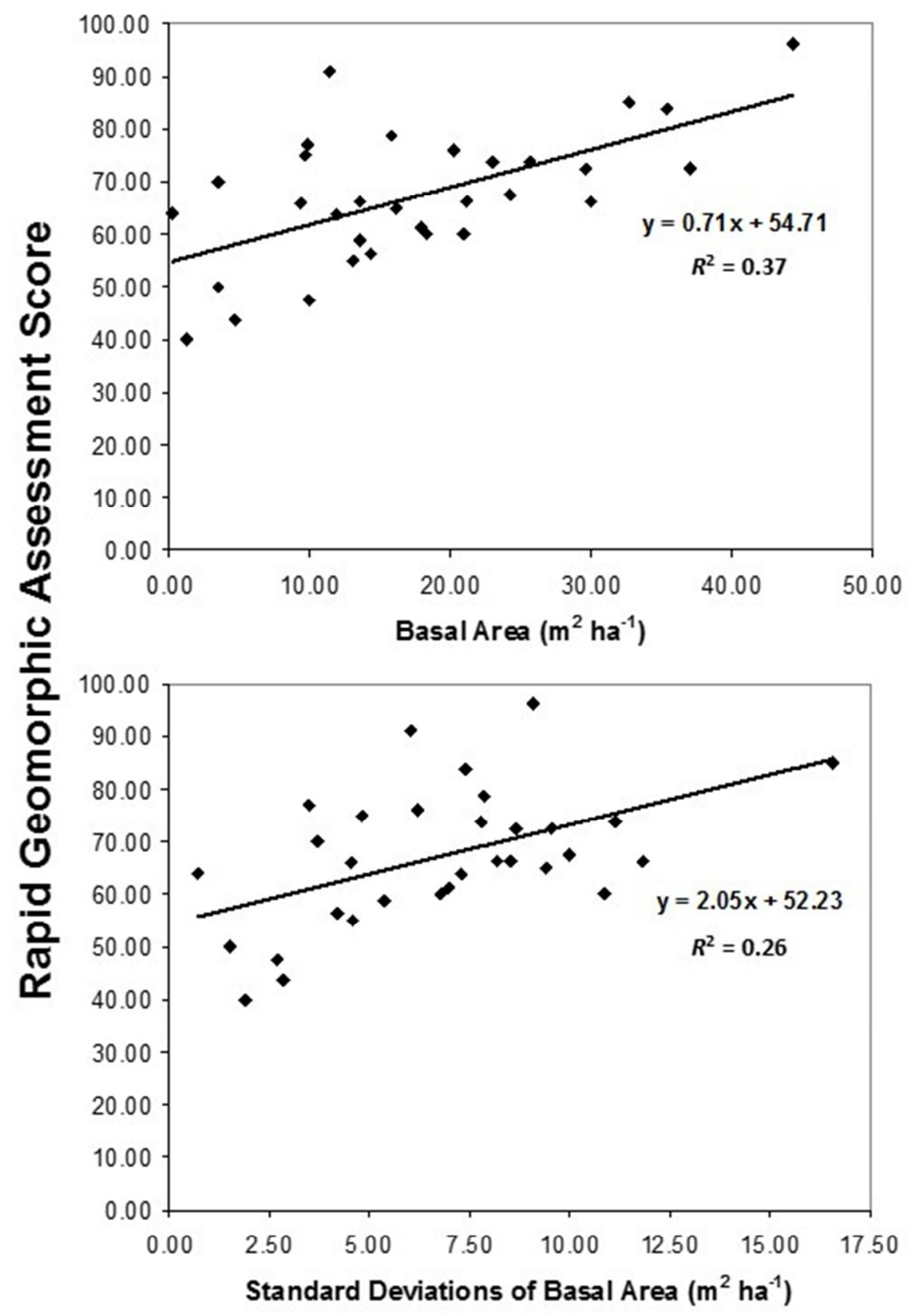
2 Figure 5.

3

4

5

6

7

8

11

12

13

14

15

16
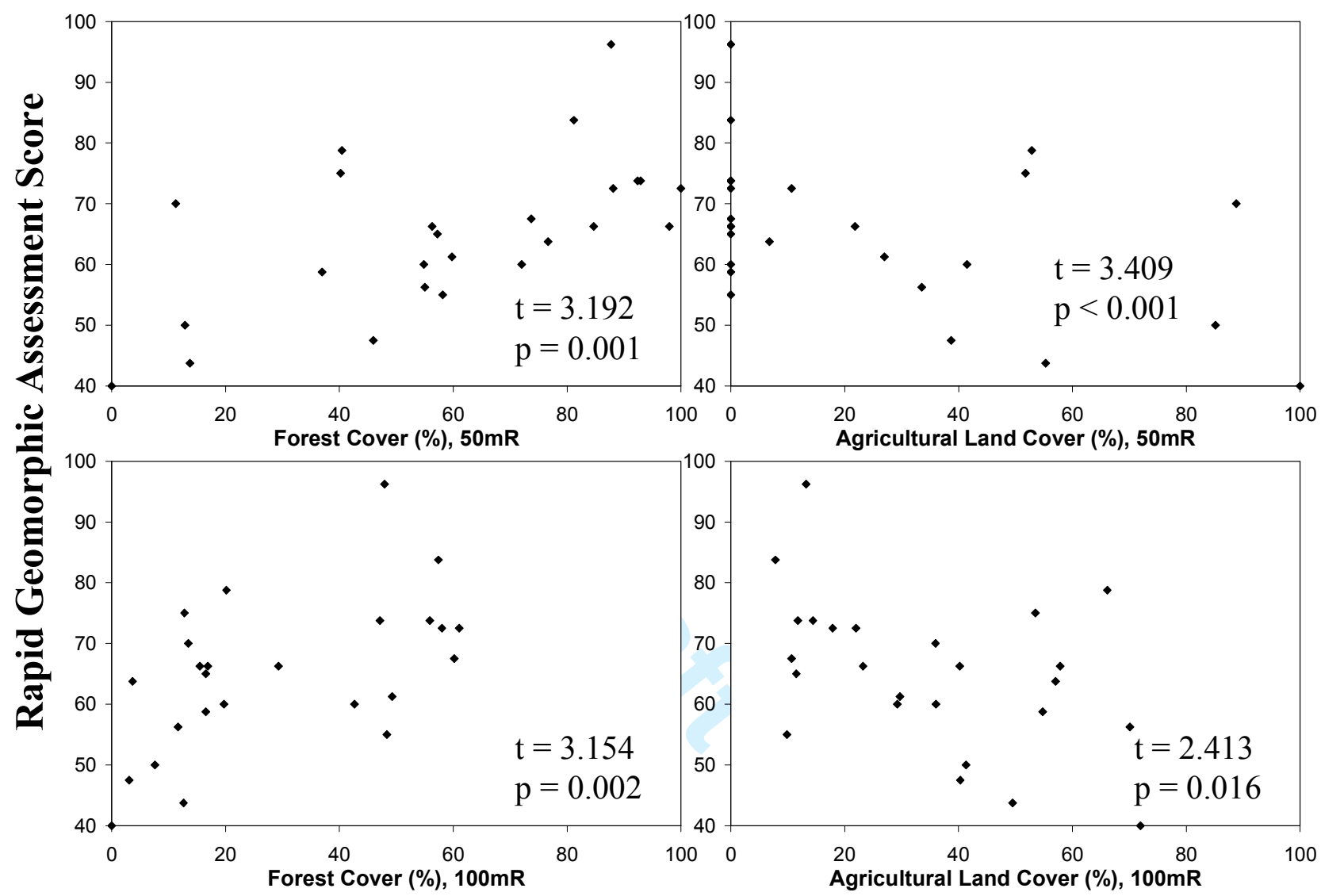

17

18

19

20

21

22

23 